\title{
Assessment of the Potential of Honeybees (Apis mellifera L.) in Biomonitoring of Air Pollution by Cadmium, Lead and Vanadium
}

\author{
Jozef J. M. Van der Steen ${ }^{1}$, Joop de Kraker ${ }^{2}$, Tim Grotenhuis ${ }^{3}$ \\ ${ }^{1}$ Plant Research International, Wageningen, Netherlands \\ ${ }^{2}$ School of Science, Open Universiteit, Heerlen, Netherlands \\ ${ }^{3}$ Section Environmental Technology, Wageningen University, Wageningen, Netherlands \\ Email: ${ }^{*}$ sjef.vandersteen@wur.nl
}

Received 21 January 2015; accepted 2 February 2015; published 11 February 2015

Copyright (C) 2015 by authors and Scientific Research Publishing Inc.

This work is licensed under the Creative Commons Attribution International License (CC BY). http://creativecommons.org/licenses/by/4.0/

\section{Abstract}

The aim of our study was to explore whether honeybees (Apis mellifera L.) could be used as a reliable alternative to the standard mechanical devices for monitoring of air quality, in particular with respect to the concentration of the heavy metals cadmium (Cd), lead (Pb) and vanadium (V). We therefore tested whether the concentrations of these metals in adult honeybees and in ambient air were positively correlated, and whether differences in concentration between locations were similar for bees and air. On the basis of our measurements, conducted over a two-month period at three distinct locations in the Netherlands with each three replicate honeybee colonies placed next to mechanical monitoring devices, we concluded that a significant positive relationship between the concentrations in bees and in air could only be established for V. Also, only in the case of $\mathrm{V}$, the differences between the three locations in mean concentration were similar for bees and air. Both outcomes were probably due to the relatively large range over which the concentrations of $\mathrm{V}$ varied, both in bees and in air, as compared to $\mathrm{Cd}$ and $\mathrm{Pb}$. However, for $\mathrm{V}$, as well as for $\mathrm{Cd}$ and $\mathrm{Pb}$, the concentrations in ambient air were about two orders of magnitude below the established air quality standards. We therefore conclude that in the Netherlands, both variation and levels of the atmospheric concentrations of these metals are too low to establish a relationship between the concentration in bees and in air that is useful to present honeybees as an alternative to mechanical devices in monitoring of air pollution. However, in countries with larger variation and higher levels of the atmospheric concentrations of these metals, further exploration of the potential of honeybees in biomonitoring of air pollution may be worthwhile.

\footnotetext{
${ }^{*}$ Corresponding author.

How to cite this paper: Van der Steen, J.J.M., de Kraker, J. and Grotenhuis, T. (2015) Assessment of the Potential of Honeybees (Apis mellifera L.) in Biomonitoring of Air Pollution by Cadmium, Lead and Vanadium. Journal of Environmental Protection, 6, 96-102. http://dx.doi.org/10.4236/jep.2015.62011
} 


\section{Keywords}

\section{Cadmium, Lead, Vanadium, Air Pollution, Biomonitoring, Honeybee}

\section{Introduction}

Honeybees (Apis mellifera L.) are potentially highly useful to monitor environmental pollution, given their worldwide usage for honey production and pollination and their wide-ranging foraging behavior [1] [2]. Not surprisingly, studies on the use of honeybees and bee products for environmental monitoring have a relatively long history, dating back to at least 1935 [3]. Environmental pollutants included in these studies were, among others, heavy metals, which the bees may take up from all environmental compartments: vegetation, soil, air and water [4]-[8]. A recent study by Van der Steen [9] indicated that adult honeybees can serve to detect temporal and spatial patterns in environmental concentrations of a wide range of heavy metals. For seven of the metals included in their study, viz., arsenic (As), cadmium (Cd), chromium (Cr), manganese (Mn), nickel (Ni), lead (Pb) and vanadium (V), air quality standards have been established by national, European and international authorities [10]-[12]. The standards concern Maximum Tolerated Risk (MTR) values for the concentrations of these metals in the air, and aim to prevent adverse effects on human health from air pollution. In the Netherlands, a country-wide air quality monitoring system is in place, using fixed-point mechanical monitoring devices to assess whether air quality standards are met [13].

The aim of the study we report here, was to explore whether adult honeybees could be used as a reliable alternative to the standard mechanical monitoring devices to assess significant changes in the concentration of heavy metals in the air and to detect possible exceeding of MTR values. To that end, we designed an experiment in which bee colonies were placed side-by-side with mechanical monitoring devices at various locations over a prolonged period, during which regular samples were taken from bees and air and analyzed for heavy metals. We considered that bees would be a reliable alternative in the case of the metal concentrations found in bees and in air which would positively correlate, and when possible significant differences in concentration between locations would be similar for bees and air. In contrast to Balestra et al. [14] who studied honey, pollen and bee larvae, we chose to study the metal concentrations in adult worker bees as these are considered to provide more sensitive, reliable and up-to-date information about exposure of bees to metals in the environment than metal concentrations in pollen, honey and larvae [4] [7] [8] [15]-[17]. We report here the results for the heavy metals $\mathrm{Cd}, \mathrm{Pb}$ and $\mathrm{V}$. The heavy metals $\mathrm{As}, \mathrm{Cr}, \mathrm{Mn}$, and $\mathrm{Ni}$ are not included, because these metals either occur in relatively high natural concentrations in bee food sources such as pollen [18], or occur in commonly used components of beehives [9].

\section{Materials and Methods}

At three distinct locations in the Netherlands, honeybee colonies were placed next to standard air quality monitoring devices. Each honeybee colony was sampled four times over a two-month period. The concentrations of metals $(\mathrm{Cd}, \mathrm{Pb}$ and $\mathrm{V})$ in the sampled honeybees were compared with the concentrations of these metals in the air as determined with the standard monitoring devices. Per metal, statistical analyses were conducted to assess the relationship between the concentrations in honeybees and in air.

\subsection{Study Locations}

Location Maastricht, Limburglaan. Maastricht is an urban area with cement industry and glass industry, and is located close to large industrial areas such as Liège in Belgium. The honeybee colonies were placed near the city centre, on the roof of the provincial environmental research laboratory.

Location Buggenum, Dorpstraat. Buggenum is a village in a rural area about 60 kilometres north of Maastricht. In Buggenum bricks are produced and a large electric power plant is situated next to the village. This plant is powered by coal, natural gas and biomass.

Location Hoek van Holland, Prins Hendrikstraat. Hoek van Holland is situated in the Rijnmond region at the river mouth of the Nieuwe Waterweg, at the North Sea coast. The Rijnmond region includes the port of Rotter- 
dam and a large industrial area where, among others, petrochemical industry, tank storage and tank transfer, and waste treatment plants are situated.

\subsection{Honeybee Sampling Method}

Honeybee (Apis mellifera) colonies were kept from winter till summer in the same apiary in Wageningen (The Netherlands) until distribution over the three locations. At each location, three honeybee colonies (replicates) were placed. The colonies were kept in one-storey wooden hives with ten frames (Simplex measures NEN 06150). This is the most common, commercially used type of hive in the Netherlands. Each honeybee colony was sampled four times with 14-day intervals during a two-month period (7 July-1 September 2006). A random sample of 100 to 150 worker honeybees was taken from the first frame next to the brood nest that was occupied with bees but without brood. Hive bees were sampled rather than forager bees from the flight entrance as this is much more practical and forager bees constitute a stable fraction of the bees on the sampled frames [19]. Bees sampling was done by brushing bees with a plastic brush into a plastic container. The samples were transported in a cooler box and stored in the freezer at $-20^{\circ} \mathrm{C} \pm 5^{\circ} \mathrm{C}$ until analysis.

\subsection{Measurement of Metal Concentrations in Bees}

From each sample (i.e., from each combination of colony, sampling date and location), 25 frozen worker bees were taken at random. The bees were subsequently weighed, dried during 24 hours at $120^{\circ} \mathrm{C}$, weighed, and destructed by boiling the sample at $170^{\circ} \mathrm{C}$ in a mixture of $25 \mathrm{ml} \mathrm{HNO}_{3}(70 \%)$ and $\mathrm{HCl}(37 \%)$ at a ratio of 1:3 (aqua regia). The resulting liquid was topped up to $50 \mathrm{ml}$ with demi-water. The chemical analyses on metals were carried out by the environmental research laboratory of the Province of Limburg (The Netherlands), using the inductive coupled plasma-atomic emission spectrometry (ICP-AES) technique. Five milliliters of the $50 \mathrm{ml}$ was filtered over a cotton wool filter and analyzed using ICP-AES. The measured metal concentrations (ng $\cdot \mathrm{mL}^{-1}$ ) were converted to $\mathrm{ng} \cdot \mathrm{g}^{-1} \cdot \mathrm{dm}$ bee $(\mathrm{ppb})$ with a conversion factor (volume sample/(weight bees $\times$ mean percentage dry weight)), resulting in ppb metal in dry weight which was subsequently converted to micrograms per gram dry material bee $\left(\mu \mathrm{g} \cdot \mathrm{g}^{-1} \cdot \mathrm{dm}\right)$. The overall weight loss of the bee samples as a result of the drying process was $68 \%$.

\subsection{Measurement of Metal Concentrations in Air}

At Maastricht and Buggenum, measurements of the atmospheric concentration of the metals were taken daily with fixed mechanical monitoring devices operated by the provincial environmental and water research service (Hoofdgroep Milieu en Water, Bureau Onderzoek en Advies, Provincie Limburg). The devices are high volume air samplers, which press $680 \mathrm{~m}^{3}$ air through glass-fibre filters in 24 hours. At Hoek van Holland, the measurements were taken at six-day intervals with a fixed monitoring device operated by the regional environmental management service (Dienst Centraal Milieubeheer Rijnmond, DCMR). Here, the device is a high volume air sampler, which presses $668 \mathrm{~m}^{3}$ air through quartz filters in 24 hours. The filters were analysed for the metals in the laboratory using the same technique as for the bee samples (ICP-AES). The concentrations of heavy metals in the air were expressed in nanograms per $\mathrm{m}^{-3}\left(\mathrm{ng} \cdot \mathrm{m}^{-3}\right)$ air.

\subsection{Statistical Analyses}

The aim of the statistical analyses was to assess for each metal the relationship between the concentrations in honeybees and in air. The analyses were performed in Genstat $16^{\text {ed }}$. In a first analysis, the relationship between the concentration of a metal in honeybees $\left(\mu \mathrm{g} \cdot \mathrm{g}^{-1}\right)$ and the concentration of the same metal in the air (ng $\cdot \mathrm{m}^{-3}$ ) was assessed with logarithmic regression. For the analysis, the metal concentration in bees was calculated as the average value of the three bee colonies (replicates) per location and sampling date, and the metal concentration in the air was calculated as the average of all air samples taken during the 14-day period preceding the sampling of the bees. All averages of concentration data were calculated by log-transformation of the raw data followed by back-transformation of the average of the log-transformed data. The regression analysis was conducted per metal, with concentration in bees as the dependent factor and concentration in air as the independent factor. The data of the four sampling times and three locations were pooled on the assumption that the relationship between the metal concentration in bees and air should be independent of time and place to be useful in biomonitoring. 
The data were checked for significant outliers with Grubbs' test (alpha $=0.05)$ and analyses were conducted with and without outliers. As outliers did not affect the conclusions, we did not exclude outliers from the data and analyses. A second analysis concerned the correspondence in spatial variation between the metal concentrations in honeybees and air. Per metal, a Generalized Linear Mixed Model (GLMM) analysis was done assuming a lognormal distribution of the concentration data. Spatial differences in concentration were assessed separately for honeybees and air, by comparing, between locations, the mean values of all measurements during the entire two-month study period. Differences in concentrations between locations were considered significant at $\mathrm{P}$ values $\leq$ 0.05, using Tukey's Multiple Comparisons test.

\section{Results and Discussion}

Regression analysis of pooled data (covering four sampling times and three locations) yielded a highly significant, positive relationship between the concentration of $\mathrm{V}$ in honeybees and in air. Another highly significant, but negative relationship was found between the concentration of $\mathrm{Cd}$ in honeybees and in air. No significant relationship was found between the concentration of $\mathrm{Pb}$ in honeybees and in air. For the significant relationships, the regression lines are included in Figure 1 and the corresponding regression equations and other statistics are presented in Table 1.

The correspondence in spatial variation between the metal concentrations in honeybees and air was tested. Table 2 presents the results of the analyses of spatial variation in the metal concentrations, for honeybees and air. In honeybees, significant differences in concentration between locations were found for $\mathrm{Cd}$ as well as for $\mathrm{V}$. In air, the mean concentrations over the entire two-month study period of $\mathrm{Cd}, \mathrm{Pb}$ and $\mathrm{V}$, differed significantly between the three locations. Only in the case of V, there was correspondence in spatial variation between the metal concentrations in honeybees and air, with significantly higher concentrations in Hoek van Holland than in Maastricht and Buggenum. In the case of $\mathrm{Cd}$, there was no correspondence in spatial variation between the metal concentrations in honeybees and air. For honeybees, the highest Cd concentrations were found in Buggenum, whereas for air, the lowest $\mathrm{Cd}$ concentrations were found there.

The concentrations of $\mathrm{Cd}, \mathrm{Pb}$ and $\mathrm{V}$ measured in honeybees and air over the test period are presented in Figure 2 separately for the three study locations.

On the basis of our measurements, conducted at three distinct locations in the Netherlands over a two-month period, a significant positive relationship between the concentrations in bees and in air could only be established for vanadium (Table 2). Also, only in the case of vanadium, the differences between the three locations in mean
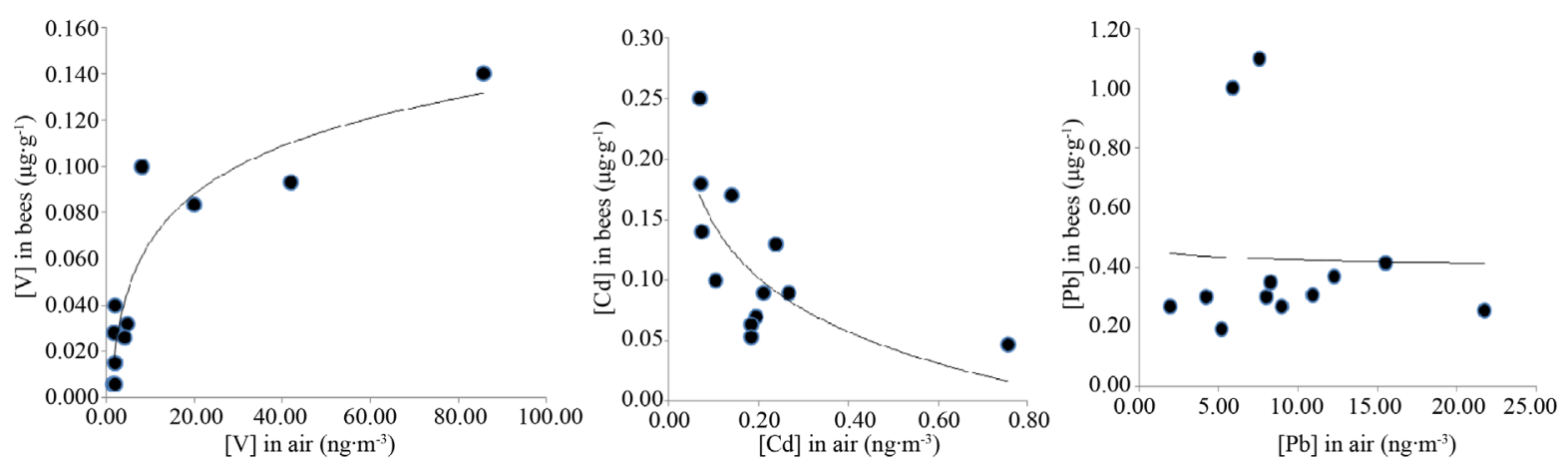

Figure 1. Scatter plots (with regression lines) of concentrations of $\mathrm{V}, \mathrm{Cd}$ and $\mathrm{Pb}$ in air (ng.m $\mathrm{m}^{-1}$ ) versus $\mathrm{V}, \mathrm{Cd}$ and $\mathrm{Pb}$ $\left(\mu \mathrm{g} \cdot \mathrm{g} \cdot \mathrm{bee}^{-1} \cdot \mathrm{dm}\right)$. Data points represent the pooled results from all sampling dates and locations.

Table 1. Logarithmic regression of concentrations of $\mathrm{Cd}, \mathrm{Pb}$ and $\mathrm{V}$ in honeybees $\left(\mathrm{y}, \mu \mathrm{g} \cdot \mathrm{g}^{-1} \cdot \mathrm{dm}\right)$ and in air $\left(\mathrm{x}, \mathrm{ng} \cdot \mathrm{m}^{-3}\right): \mathrm{re}-$ gression equations, $\mathrm{P}$ values of regression and the $\mathrm{R}^{2}$ values (percentage variance accounted for).

\begin{tabular}{cccc}
\hline Element & Regression equation & $\mathrm{P}$ & $\mathrm{R}^{2}$ \\
\hline $\mathrm{Cd}$ & $\mathrm{y}=-0.06 \ln (\mathrm{x})-0.001$ & 0.008 & $48 \%$ \\
$\mathrm{~Pb}$ & $\mathrm{y}=-0.016 \ln (\mathrm{x})+0.46$ & 0.92 & $0 \%$ \\
$\mathrm{~V}$ & $\mathrm{y}=0.030 \ln (\mathrm{x})-0.0017$ & $<0.001$ & $84 \%$ \\
\hline
\end{tabular}


Table 2. Metal concentrations in worker bees $\left(\mu \mathrm{g}^{-1} \cdot \mathrm{dm}\right)$ and air $\left(\mathrm{ng} \cdot \mathrm{m}^{-3}\right)$ from three locations, calculated as sample means over the entire sampling period (7 July-1 September 2006).

\begin{tabular}{cccc}
\hline Element & Maastricht & Buggenum & Hoek van Holland \\
\hline$[$ Bees $]$ & & & $0.06^{\mathrm{a}}$ \\
$\mathrm{Cd}$ & $0.10^{\mathrm{ab}}$ & $0.16^{\mathrm{b}}$ & $0.41^{\mathrm{a}}$ \\
$\mathrm{Pb}$ & $0.33^{\mathrm{a}}$ & $0.36^{\mathrm{a}}$ & $0.10^{\mathrm{b}}$ \\
$\mathrm{V}$ & $0.02^{\mathrm{a}}$ & $0.013^{\mathrm{a}}$ & $0.30^{\mathrm{b}}$ \\
[Air $]$ & & & $4.89^{\mathrm{a}}$ \\
$\mathrm{Cd}$ & $0.17^{\mathrm{b}}$ & $0.07^{\mathrm{a}}$ & $27.94^{\mathrm{b}}$ \\
$\mathrm{Pb}$ & $12.53^{\mathrm{b}}$ & $7.55^{\mathrm{a}}$ & $2.18^{\mathrm{a}}$ \\
$\mathrm{V}$ & $1.81^{\mathrm{a}}$ & 2.59
\end{tabular}

Different superscript letters indicate per location (row) statistically significant differences between sample means.
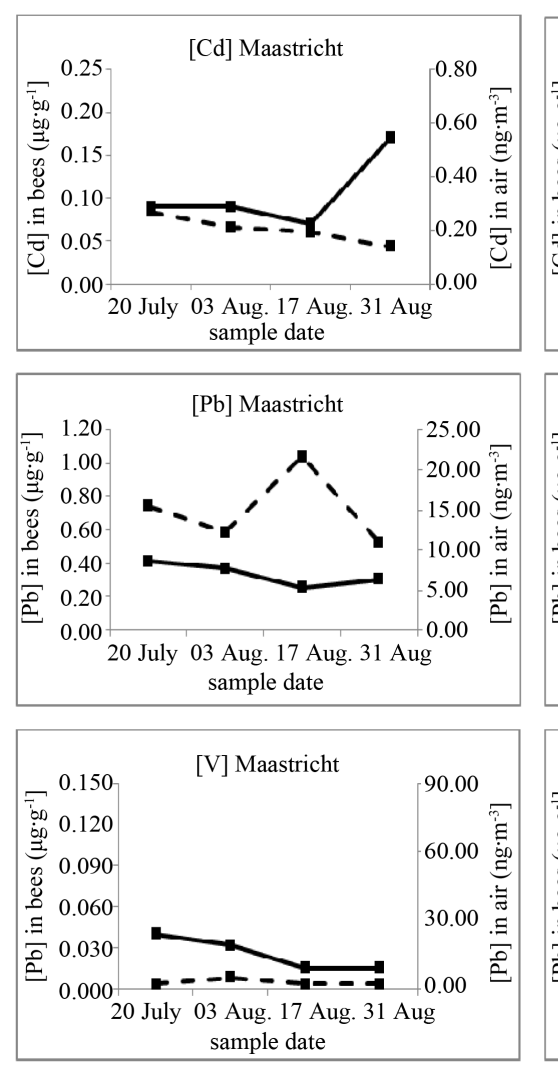
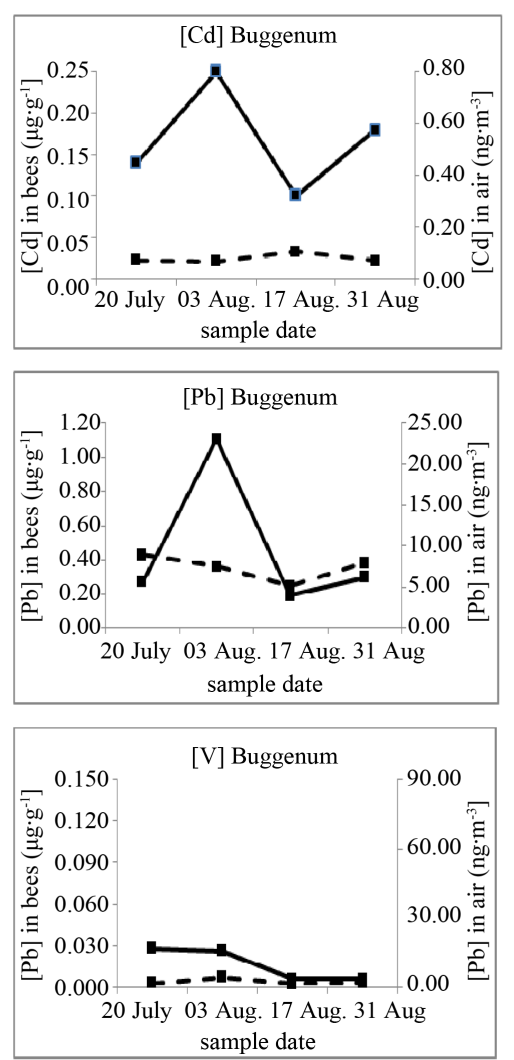
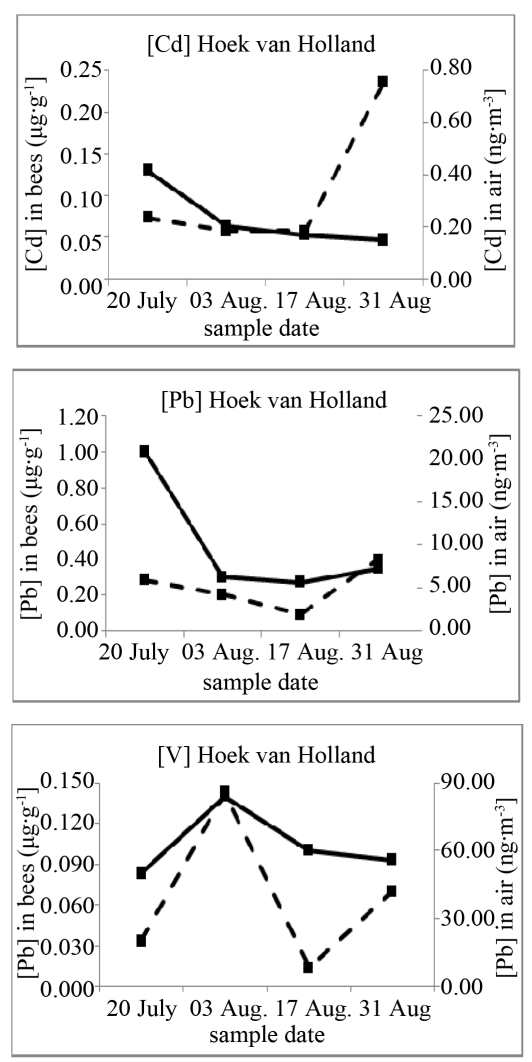

Figure 2. Concentrations of $\mathrm{Cd}, \mathrm{Pb}$ and $\mathrm{V}$ in worker honeybees $\left(\mu \mathrm{g} \cdot \mathrm{g}^{-1} \cdot \mathrm{dm}\right.$, drawn line) and air $\left(\mathrm{ng} \cdot \mathrm{m}^{-3}\right)$, dashed line in samples from three locations. The sample date (x axis) refers to the sampling period (air) and sample dates (honeybees). The sample dates of the honeybees correspond with the sampling periods of air (between brackets), as follows: 20 July (7-20 July); 03 Aug. (21 July-3 August); 17 Aug. (4-17 August); 31 Aug. (18-31 August).

concentration were similar for bees and air (Table 2). Both outcomes are probably due to the relatively large range over which the concentrations of $\mathrm{V}$ varied, both in bees and in air, as compared to $\mathrm{Cd}$ and $\mathrm{Pb}$. For $\mathrm{V}$, measured concentrations differed by 1 - 2 orders of magnitude, whereas for $\mathrm{Cd}$ and $\mathrm{Pb}$ this was less than one order of magnitude (Figure 1, Table 1). The larger the variation in measured concentrations, the higher the probability to detect significant, meaningful relationships.

With regard to the potential of honeybees in biomonitoring of air pollution by heavy metals the results for $\mathrm{V}$ are promising. However, the concentrations of $\mathrm{V}$ in air measured in our study were about two orders of magni- 
tude below the air quality standard for $\mathrm{V}\left(1000 \mathrm{ng} \cdot \mathrm{m}^{-3}\right)$ [13], and extrapolation of a statistical relationship beyond the range over which it is established is not allowed. To warrant a conclusion on the reliability of honeybee biomonitoring as an alternative to the standard mechanical monitoring, the positive relationship found between the concentrations of $\mathrm{V}$ in bees and in air, should thus also be tested for situations in which the concentration of $\mathrm{V}$ in air exceeds $1000 \mathrm{ng} \cdot \mathrm{m}^{-3}$.

For $\mathrm{Cd}$ and $\mathrm{Pb}$, our results seem to indicate that there is no potential for honeybees in biomonitoring of air pollution by these heavy metals. As indicated above, however, this may be due to the limited range over which the concentrations of $\mathrm{Cd}$ and $\mathrm{Pb}$ varied in our study. The work of Bromenshenk et al. [20] points in this direction. They found that the concentrations of $\mathrm{Cd}$ and $\mathrm{Pb}$ in weekly sampled worker bees were significantly and positively correlated with the concentrations in air during the same period. Unfortunately, Bromenshenk et al. [20] did not present measurement data or any other quantitative results, but, as they located the bee colonies and air sampler near a lead smelting complex, the concentrations of $\mathrm{Cd}$ and $\mathrm{Pb}$ in the air were presumably high. In our study, the concentrations of $\mathrm{Cd}$ and $\mathrm{Pb}$ in air were relatively low and, as for $\mathrm{V}$, about two orders of magnitude below the air quality standards $\left(5 \mathrm{ng} \cdot \mathrm{m}^{-3}\right.$ for $\mathrm{Cd}$ and $500 \mathrm{ng} \cdot \mathrm{m}^{-3}$ for $\mathrm{Pb}$ ) [13]. Thus, also for $\mathrm{Cd}$ and $\mathrm{Pb}$, further testing of the relationship between the concentrations in bees and in air should be done under conditions with more variation and concentration levels exceeding the MTR values.

\section{Conclusion}

Our results indicate that in the Netherlands, both variation and levels of the atmospheric concentrations of these metals are too low to establish a useful relationship between the concentration in bees and in air. Under these conditions, bees cannot be used as a reliable alternative to the current system in place to meet legal monitoring requirements. However, our results positively indicate for $\mathrm{V}$, and do not exclude for $\mathrm{Cd}$ and $\mathrm{Pb}$, that a relationship between the concentrations in bees and in air can be established and applied for biomonitoring purposes. This should be done under conditions of relatively high variation, with atmospheric concentrations of these metals differed by several orders of magnitude, and maximum levels exceeding the MTR values. In countries where these conditions apply, we consider further exploration of the potential of honeybees as an alternative to the establishment of a costly mechanical monitoring network worthwhile.

\section{Acknowledgements}

We thank Dr. M. Severijns, Dr. J. Pijnenburg (Provincie Limburg) and Dr. P. Kummu (DCMR Rijnmond) for their help in selecting the study locations, Ing. L. Goessen (Province of Limburg) for the chemical analyses of the samples, Mr. J. Withagen (Wageningen UR) for the statistical analyses.

\section{References}

[1] Bromenshenk, J. and Preston, E.M. (1986) Public Participation in Environmental Monitoring: A Means of Attaining Network Capability. Environmental Monitoring and Assessment, 6, 35-47. http://dx.doi.org/10.1007/BF00394286

[2] Raeymaekers, B. (2006) A Prospective Biomonitoring Campaign with Honey Bees in a District of Upper-Bavaria (Germany). Environmental Monitoring and Assessment, 116, 233-243. http://dx.doi.org/10.1007/s10661-006-7389-8

[3] Crane, E. (1984) Bees, Honey and Pollen as Indicators of Metals in the Environment. Bee World, 55, 47-49.

[4] Bromenshenk, J.J., Carlson, S.T., Simpson, J.C. and Thomas, J.M. (1985) Pollution Monitoring of Puget Sound with Honey Bees. Science, 227, 632-634. http://dx.doi.org/10.1126/science.227.4687.632

[5] Conti, M.E. and Botré, F. (2001) Honeybees and Their Products as Potential Bio-Indicators of Heavy Metal Contamination. Environmental Monitoring and Assessment, 69, 267-282. http://dx.doi.org/10.1023/A:1010719107006

[6] Leita, L., Muhlbachova, G., Cesco, S., Barbattini, R. and Mondini, C. (1996) Investigation of the Use of Honey Bees and Honey Bee Products to Assess Heavy Metals Contamination. Environmental Monitoring and Assessment, 43, 1-9. http://dx.doi.org/10.1007/BF00399566

[7] Mihaly Cozmuta, A., Bretan, L., Mihaly Cozmuta, L., Nicula, C. and Peter, A. (2012) Lead Traceability along Soil-Melliferous Flora-Bee Family-Apiary Products Chain. Journal of Environmental Monitoring, 14, 1622. http://dx.doi.org/10.1039/c2em30084b

[8] Porrini, C., Sabatini, A.G., Girotti, S., Ghini, S., Medrzycki, P., Grillenzoni, F., Bortolotti, L., Gattavecchia, E. and Celli, G. (2003) Honey Bees and Bee Products as Monitors of the Environmental Contamination. Apiacta, 38, 63-70.

[9] Van der Steen, J.J.M., de Kraker, J. and Grotenhuis, T. (2012) Spatial and Temporal Variation of Metal Concentrations 
in Adult Honeybees (Apis mellifera L.). Environmental Monitoring and Assessment, 184, 4119-4126. http://dx.doi.org/10.1007/s10661-011-2248-7

[10] EU (2008) Directive 2008/50/EC of the European Parliament and of the Council of 21 May 2008 on Ambient Air Quality and Cleaner Air for Europe. Official Journal of the European Union, 1-44.

[11] Staatsblad (1997) Besluit luchtkwaliteit koolmonoxide en lood [Resolution Air Quality Carbon Monoxide and Lead]. Nr. 459.

[12] WHO (2000) Air Quality Guidelines for Europe. 2nd Edition, WHO Regional Publications, European Series, No. 91, WHO Regional Office for Europe, Copenhagen.

[13] De Jong, F.M.W. and Janssen, P.J.C.M. (2010) Road-Map Normstelling: Luchtnormen Geordend [Air Quality Standards Organized]. RIVM-Rapport 601782026, National Institute for Public Health and the Environment, Bilthoven, L 152, 1-45.

[14] Balestra, V., Celli, G. and Porrini, C. (1992) Bees, Honey, Larvae and Pollen in Biomonitoring of Atmospheric Pollution. Aerobiologia, 8, 122-126. http://dx.doi.org/10.1007/BF02291339

[15] Fakhimzadeh, K. and Lodenius, M. (2000) Heavy Metals in Finnish Honey, Pollen and Honey Bees. Apiacta, 35, 8595.

[16] Jones, K.C. (1987) Honey as an Indicator of Heavy Metal Contamination. Water, Air, and Soil Pollution, 33, 179-189. http://dx.doi.org/10.1007/BF00191386

[17] Veleminsky, M., Laznicka, P. and Stary, P. (1990) Honeybees (Apis mellifera) as Environmental Monitors of Heavy Metals in Czechoslovakia. Acta Entomologica Bohemoslovaca, 87, 37-44.

[18] Lambers, H., Chapin III, F.S. and Pons, T.L. (1998) Plant Physiological Ecology. Springer, New York. http://dx.doi.org/10.1007/978-1-4757-2855-2

[19] Van der Steen, J.J.M., Cornelissen, B., Donders, J., Blacquière, T. and Van Dooremalen, C. (2012) How Honey Bees of Successive Age Classes Are Distributed over a One Storey, Ten Frames Hive. Journal of Apicultural Research, 51, 174-178. http://dx.doi.org/10.3896/IBRA.1.51.2.05

[20] Bromenshenk, J.J., Gudatis, J.L., Cronn, R.C. and Olbu, G.J. (1988) Uptake and Impact of Heavy Metals to Honey Bees. American Bee Journal, 128, 800-801. 
Scientific Research Publishing (SCIRP) is one of the largest Open Access journal publishers. It is currently publishing more than 200 open access, online, peer-reviewed journals covering a wide range of academic disciplines. SCIRP serves the worldwide academic communities and contributes to the progress and application of science with its publication.

Other selected journals from SCIRP are listed as below. Submit your manuscript to us via either submit@scirp.org or Online Submission Portal.
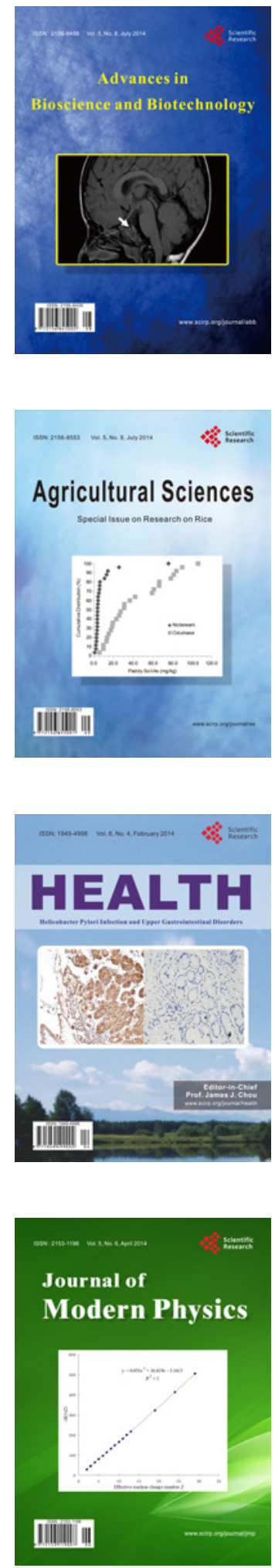
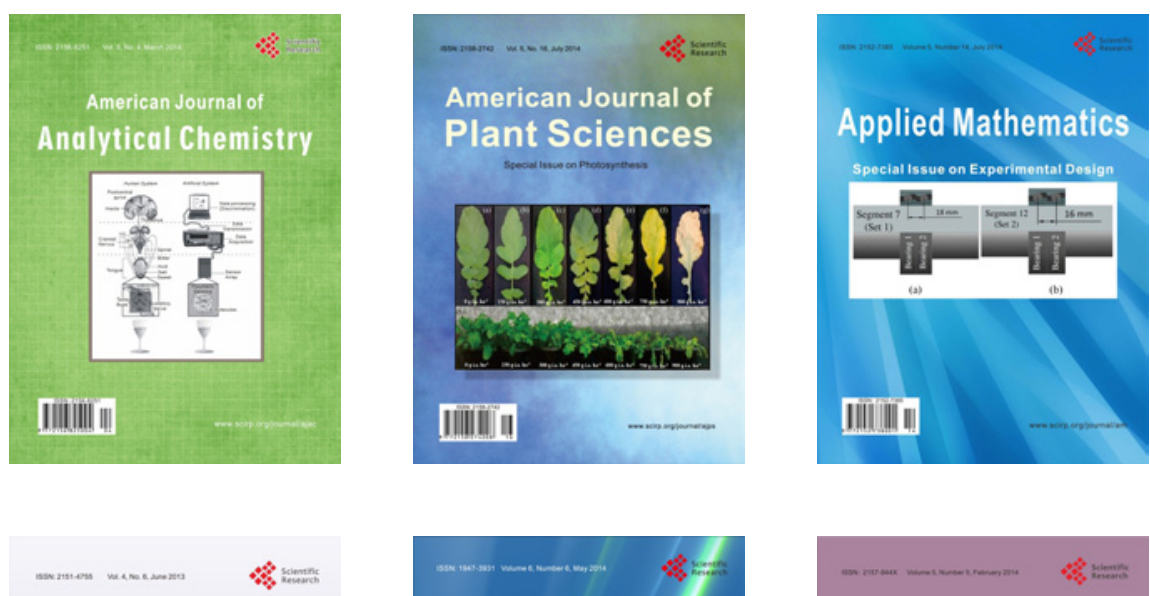

Creative Education
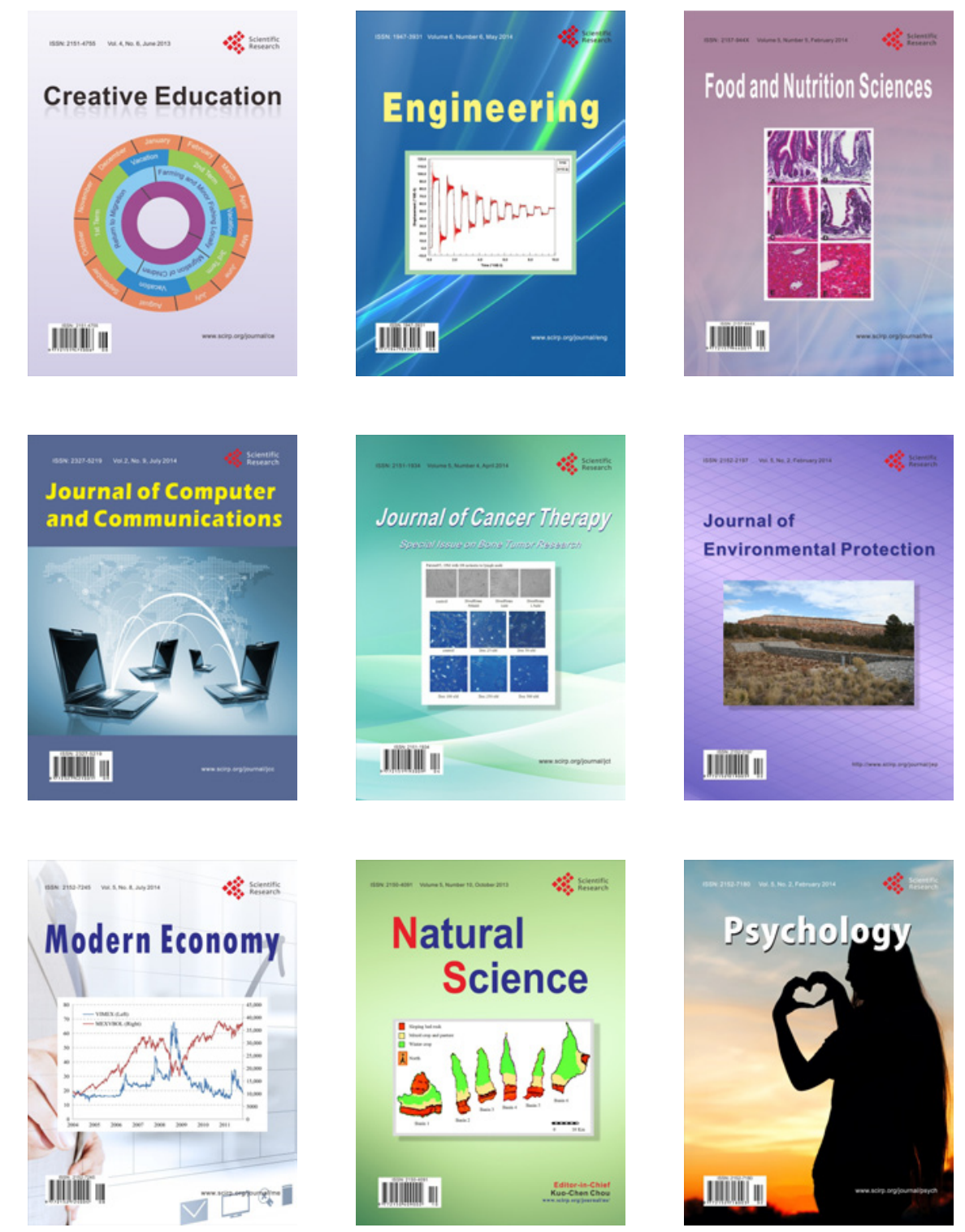